\title{
DIETARY PHENOLICS AND ANTIOXIDANT CAPACITY OF SELECTED LEGUMES SEEDS FROM THE CENTRAL BALKANS
}

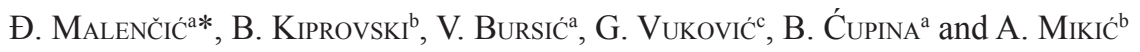 \\ ${ }^{\mathrm{a}}$ Faculty of Agriculture, University of Novi Sad, Trg Dositeja Obradovića 8, 21000 Novi Sad, Serbia \\ ${ }^{b}$ Institute of Field and Vegetable Crops, Maksima Gorkog 30, 21000 Novi Sad. Serbia \\ ${ }^{c}$ Institute of Public Health of Belgrade, Bulevar Despota Stefana 54, 11000 Belgrade. Serbia
}

(Received: 2 November 2017; accepted: 17 February 2018)

\begin{abstract}
The aim of this study was to select Vicia genotypes with higher polyphenol contents and increased antioxidant activity, and to compare them with soybean, the most widespread and utilized legume species grown in the region. The examined legumes showed similar contents of total polyphenolics and tannins in between specimen, but differed greatly in their flavonoids and proanthocynidins levels. The content of total polyphenols ranged from 1.6 to 6.09 catechin/g dry seeds, and tannins from 0.26 to $2.98 \mathrm{mg}$ of catechin/g dry seeds. The flavonoids levels in Vicia species were much higher compared with soybean, while the content of proanthocyanidins ranged from 1.5 (in soybean) to $62.3 \mathrm{mg}$ of leucoanthocyanidin/g dry seeds (in vetches). The gallic and trans-cinnamic acids were identified as major monomeric phenolic compounds, and quercetin among flavonoids was found in all specimens. Catechin was detected in faba bean and vetches but not in the soybean. The values of the DPPH-test varied in a range between 21.1 and $89.6 \%$ of neutralized radicals, which correlated with the total polyphenolics and tannin contents. The faba bean specimens showed favourable traits - high total polyphenolic, flavonoid and proanthocyanidin contents, low total tannin content, and high DPPH-radical scavenging ability.
\end{abstract}

Keywords: faba bean, vetches, soybean, plant phenolics, antioxidant activity, functional food

Legumes (Fabaceae) represent one of the most widely distributed plant families in the Balkans (Southeast Europe). The local wild and agricultural flora in the Balkan countries and other Eastern European regions are rather rich in legume species. Among these are faba bean (Vicia faba L.), vetches (Vicia spp.), vetchlings (Lathyrus spp.), lentil (Lens culinaris), pea (Pisum sativum L.), chickpea (Cicer arietinum), lupins (Lupinus spp.), and Phaseolus beans (Mırıć et al., 2011). On the other hand, soybean (Glycine max L.), pea, lentil, and Phaseolus beans are the typical representatives of agricultural flora, where they play an important role in human and animal nutrition and are the main sources of plant proteins. Many of these species have become underutilized and nearly forgotten crops, as in most parts of Southeast Europe soybean and Phaseolus bean are more favoured, as those are are easier to be fitted in modern crop rotations (MiнAILOvić et al., 2010). Other species such as vetches and vetchlings also remain a part of wild flora despite their great agronomic potential with unexplored agronomic properties and non-defined role in natural grassland systems (Mikić et al., 2009). Faba bean seeds supply protein-rich feed stuff and provide a valuable composition with a useful balance of carbohydrate, fibre, micronutrient, and phytochemicals. However, faba bean contains anti-nutritive compounds, which limit its use in feed and food systems, with unhealthy impact on humans and several animals, such as tannins, vicine, and convicine.

\footnotetext{
* To whom correspondence should be addressed. Phone: +381214853401; e-mail: malencic@polj.uns.ac.rs
} 
Tannins are considered to be the main factor of low faba bean protein digestibility (PUSPITASARI, 2017).

In the last decade, functional foods have been a developing area of food science research. Many foods are derived from plants that naturally contain compounds beneficial to human health and can prevent certain diseases. This has led to the creation of functional foods to target health problems such as obesity and inflammation. These plant compounds may possess key beneficial properties including antioxidant activity, anti-inflammation activity, cholesterol lowering ability, and even anticancer activity (EMmons \& Peterson, 2001). Polyphenols have also been reported to possess antibacterial, antimutagenic, antiinflammatory, and vasodilatory properties (AMIDžIĆ-KLARIĆ et al., 2011). Phenolics may act as antioxidants, thereby reducing the risk of atherosclerosis and coronary heart disease, which can be caused by the oxidation of low-density lipoproteins (MALENČIĆ et al., 2007). For these reasons, polyphenol-enriched foods would be classified as functional foods. The positive effects of legume seeds and their possible health benefits in human nutrition have commanded considerable attention. In human studies it has been demonstrated that $V$. faba protein has hypocholesterolemic effect, comparable to that of soybean protein (GoyOAGA et al., 2011).

Since there is a lack of lietrature, our goal was to contribute to possible benefitial feed and food properties of these underutilized legumes grown in the Balkans.

\section{Materials and methods}

\subsection{Plant materials and chemicals}

Five samples of seeds of faba bean (Vicia faba L.) and 5 samples of vetches [Vicia narbonensis L., V. serratifolia Jacq., V. sativa L., V. ervilia (L.) Wild., and V. pannonica Crantz] were analysed and compared with 5 commercially grown soybean cultivars (Balkan, Alisa, Tara, Venera and Morava). The specimen of faba beans and two vetches ( $V$. serratifolia and $V$. narbonensis) were collected in the summer of 2015, from the local autochthonous populations from different localities in Serbia - V. faba from Lazarevac $\left(44^{\circ} 21^{\prime} \mathrm{N}, 20^{\circ} 14^{\prime} \mathrm{E}\right)$, Parunovac $\left(43^{\circ} 33^{\prime} \mathrm{N}, 21^{\circ} 22 \mathrm{E}\right)$, Tekija $\left(44^{\circ} 39^{\prime} \mathrm{N} 22^{\circ} 20^{\prime} \mathrm{E}\right)$, Djunis $\left(43^{\circ} 34^{\prime} \mathrm{N}, 21^{\circ} 31^{\prime} \mathrm{E}\right)$, and Selenča $\left(45^{\circ} 24^{\prime} \mathrm{N}, 19^{\circ} 15^{\prime} \mathrm{E}\right) ; \mathrm{V}$. narbonensis from Pirot, $\left.43^{\circ} 10^{\prime} \mathrm{N}, 22^{\circ} 32^{\prime} \mathrm{E}\right)$; V. serratifolia from Hopovo, $45^{\circ} 07^{\prime} \mathrm{N}, 19^{\circ} 50^{\prime} \mathrm{E}$ ), and one from western Bulgaria (Dolni Lom, 4330’ $\mathrm{N}, 22^{\circ} 47^{\prime} \mathrm{E}$ ). Other vetches and soybean cultivars were grown and collected in the same period, on the experimental fields at Rimski Šančevi, near Novi Sad, Serbia $\left(45^{\circ} 33^{\prime} \mathrm{N}, 19^{\circ} 85^{\prime} \mathrm{E}\right)$.

Acetone, formic acid, acetic acid, and EtOH (pa) were purchased from Zorka pharma (Šabac, Serbia); Folin-Ciocalteu reagent, PVPP, and DPPH from Sigma-Aldrich Co. (St. Louis, $\mathrm{MO}, \mathrm{USA}$ ); $\mathrm{Na}_{2} \mathrm{CO}_{3}, \mathrm{AlCl}_{3}$ reagent, and $\%$ ferric reagent from Centrohem (Belgrade, Serbia); butanol-HCl assay and methanol (HPLC grade) from Merck (Darmstadt, GermanyFisher Chemical, Loughborough, UK).

\subsection{Preparation of extracts}

The plant material ( $1 \mathrm{~g}$ of whole seeds) was ground in a mill, reduced to a fine powder, and extracted with $70 \%$ aqueous acetone $(50 \mathrm{ml}$ ) by sonication for $20 \mathrm{~min}$ in an ultrasonic bath at ambient temperature. The extracts were rapidly vacuum-filtered through a sintered glass funnel and kept refrigerated before assay. 


\subsection{Determination of total polyphenols (TP)}

Aliquots $(0.1 \mathrm{ml})$ of aqueous acetone extracts were transferred into test tubes and mixed well with Folin-Ciocalteu reagent $(0.5 \mathrm{ml})$. After $6 \mathrm{~min}, 0.4 \mathrm{ml}$ of saturated sodium carbonate solution (177 $\mathrm{g} \mathrm{Na}_{2} \mathrm{CO}_{3} / 1$ ) was added and vortexed (HAGERMANn et al., 2000). After $120 \mathrm{~min}$, the absorbance (A) of the resulting blue colored mixtures was recorded at $725 \mathrm{~nm}$ against a blank. The amount of TP was calculated as a catechin equivalent and expressed as mg of catechin/g dry seeds.

\subsection{Determination of total tannins (TT)}

TT content was determined by the Folin-Ciocalteu procedure as described above (HAGERMANN et al., 2000), after the removal of tannins by adsorption on an insoluble matrix (polyvinylpolypyrrolidone, PVPP). The insoluble, cross-linked PVPP (100 mg) was weighed into test tubes and extracts $(1 \mathrm{ml})$ were added. After $15 \mathrm{~min}$ at $4{ }^{\circ} \mathrm{C}$, the tubes were vortexed and centrifuged for $10 \mathrm{~min}$ at $4350 \mathrm{~g}$. Aliquots $(0.2 \mathrm{ml})$ were transferred into test tubes and nonabsorbed phenolics were determined as described. The calculated values were subtracted from the total phenolic contents and total tannin contents expressed as mg of catechin/g dry seeds.

\subsection{Determination of flavonoids (FLA)}

The total flavonoids were determined after the extraction of plant material $(1 \mathrm{~g}$ of whole seeds) with $20 \mathrm{ml}$ of methanol-water-acetic acid (140:50:10 v/v) as extracting solvent for 60 min (MARкhAM, 1989). Aliquots $(2.5 \mathrm{ml})$ were transferred into $50 \mathrm{ml}$ volumetric flasks and made up with water. To each $10 \mathrm{ml}$ of analysis solution, water $(2 \mathrm{ml})$ and $\mathrm{AlCl}_{3}$ reagent $(5 \mathrm{ml})$ were added, and the A was recorded at $430 \mathrm{~nm}$ against a blank. The amount of FLA was calculated as a rutin equivalent from the calibration curve of rutin standard solutions, and expressed as $\mathrm{mg}$ rutin/g dry seeds.

\subsection{Determination of proanthocyanidins (PA)}

PAs were determined by a butanol- $\mathrm{HCl}$ assay (MARKHAM, 1989). In brief, aliquots of the prepared extracts $(0.5 \mathrm{ml})$ were transferred into test tubes. After the addition of butanol- $\mathrm{HCl}$ reagent $(95: 5$ butanol- $\mathrm{HCl}, 3.0 \mathrm{ml})$ and $2 \%$ ferric reagent $(0.1 \mathrm{ml})$, the test tubes were vortexed and placed in a boiling water-bath for $60 \mathrm{~min}$. After cooling, the A values were recorded at $550 \mathrm{~nm}$ against a blank. PAs were expressed as $\mathrm{mg}$ leucoanthocyanidin/g of dry seeds, assuming that the specific A value of leucoanthocyanidin was $460 \mathrm{~nm}$.

\subsection{Determination of free radical scavenging activity (DPPH)}

1,1-diphenyl-2-picrylhydrazyl (DPPH) free radical scavenging activity was assayed according to WASHIDA and co-workers (2007). One millilitre of the absolute EtOH solution of the sample $(1: 10, \mathrm{w} / \mathrm{V})$ was mixed with a $0.5 \mathrm{mmol} \mathrm{DPPH}$ EtOH solution $(0.5 \mathrm{ml})$ and 0.1

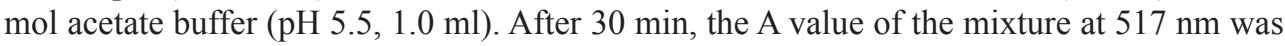
measured against a blank containing absolute EtOH $(0.5 \mathrm{ml})$ instead of a sample aliquot. DPPH-radical scavenging activity was expressed as \% of the neutralised free radicals, assuming that the sample with the higher percentage has higher scavenging capacity. The radical scavenging capacity (RSC) percentage was calculated using the formula: $\mathrm{RSC}=100$ 
$100 \times \mathrm{A}_{\text {extract }} / \mathrm{A}_{\text {blank }}$, where $\mathrm{A}_{\text {extract }}$ represents absorbance of the analysed sample extract and $\mathrm{A}_{\text {blank }}$ represents absorbance of blank sample.

\subsection{Determination of phenolic acids and flavonoids (FLA)}

The extraction of phenolic compounds for HPLC analysis of phenolic acids and FLA was carried out from $0.5 \mathrm{~g}$ of the sample with the addition of $\mathrm{EtOH}(10 \mathrm{ml})$ at constant $60{ }^{\circ} \mathrm{C}$ (Generalić et al., 2012). The phenolic acids analysis was carried out in negative electrospray ionization (ESI) mode. An Agilent 1200 (Agilent Technologies, USA) system with a binary pump was used. This was equipped with a reversed-phase C18 analytical column of $50 \times 4.6$ $\mathrm{mm}$ and $1.8 \mu \mathrm{m}$ particle size (Agilent Zorbax Eclipse XDBC18). Mobile phase was $0.1 \%$ formic acid in methanol (solvent A) and $0.1 \%$ formic acid in Milli-Q water (solvent B). The gradient was $0 \min (80 \% \mathrm{~B}), 10 \mathrm{~min}(50 \% \mathrm{~B}), 20 \mathrm{~min}(5 \% \mathrm{~B}), 24 \mathrm{~min}(0 \% \mathrm{~B}), 25 \mathrm{~min}(80 \%$

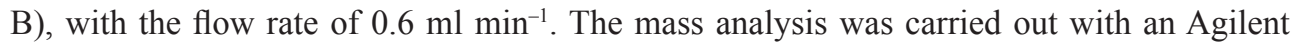
6410B Triple Quadrupole mass spectrometer equipped with multi-mode ion source (MMI) in MRM mode. The data acquisition and quantification were conducted using MassHunter Workstation software B.06.00. The following ionization conditions were used: drying gas (nitrogen) temperature $325{ }^{\circ} \mathrm{C}$, vaporizer $200{ }^{\circ} \mathrm{C}$, drying gas flow rate $51 \mathrm{~min}^{-1}$, nebulizer pressure $40 \mathrm{psi}$, and capillary voltage $2500 \mathrm{~V}$.

\subsection{Statistic analysis}

Values of the biochemical parameters were expressed as average values () \pm standard error (SE) of the determinations made in triplicates and tested by ANOVA followed by the comparisons of means by Duncan's multiple range test $(\mathrm{P}<0.05)$. The stepwise multiple linear regression analysis was used to test the correlation between antioxidant activities and investigated phenolic classes contents and expressed as a correlation coefficient (r). The data were analysed using STATISTICA for Windows version 10.0.

\section{Results and discussion}

The results obtained for phenolic contents and antioxidant activities of legume seed extracts showed great differences not only among different species but also for the specimens of the same group. The highest contents of TP, TT, and FLA, in average, were recorded in faba bean landraces (Table 1).

The contents of TP and TT in soybean cultivars were similar to those in faba beans, and significantly higher compared with vetches specimen. Most of the vetches were significantly poorer in TT, which may recommend them as a good source for ensiled livestock feed in animal husbandry. Low tannin content, especially in protein-rich plants such as legumes, is a favorable trait, because tannins are known to bind to macromolecules (proteins, structural carbohydrates, and starch) and decrease their availability to digestion (ADDISU, 2016), and thus are largely regarded as being anti-nutritional (MAKKAR, 2003). Our results for TP and TT were considerably higher (in average: $3.8 \mathrm{mg} \mathrm{g}^{-1}$ dry seeds in faba beans and $2.9 \mathrm{mg} \mathrm{g}^{-1}$ in dry seeds of vetches) compared with the results of other authors. BAGINSKY and co-workers (2013) reported TP contents in faba beans ranging from 817 to $1337 \mathrm{mg}$ of gallic acid equivalent $/ \mathrm{kg}$ and TT contents from 309 to $958 \mathrm{mg}$ gallic acid equivalent $/ \mathrm{kg}$. The mean levels of PA were $2233 \mathrm{mg} \mathrm{kg}^{-1}$, which is similar to our findings for faba bean landraces. 
Table 1. Polyphenol contents and antioxidant activity of seed extracts in selected legumes

\begin{tabular}{|c|c|c|c|c|c|}
\hline Sample $\mathrm{N}^{\mathrm{o}} /$ Locality & $\mathrm{TP}$ & $\mathrm{TT}$ & FLA & $\mathrm{PA}$ & $\mathrm{DPPH}$ \\
\hline 1. V. faba (Lazarevac) & $2.39 \pm 0.08^{\mathrm{c}}$ & $0.77 \pm 0.02^{\mathrm{c}}$ & $4.88 \pm 0.02^{b}$ & $92.40 \pm 0.31^{\mathrm{a}}$ & $52.92 \pm 1.18^{\mathrm{c}}$ \\
\hline 2. V. faba (Parunovac) & $4.18 \pm 0.31^{\mathrm{b}}$ & $1.43 \pm 0.24^{\mathrm{b}}$ & $4.70 \pm 0.01^{\mathrm{b}}$ & $17.42 \pm 0.04^{\mathrm{b}}$ & $82.85 \pm 2.10^{\mathrm{ab}}$ \\
\hline 3. V. faba (Tekija) & $6.09 \pm 0.15^{\mathrm{a}}$ & $2.98 \pm 0.08^{\mathrm{a}}$ & $3.07 \pm 0.01^{\mathrm{c}}$ & $19.32 \pm 0.04^{\mathrm{a}}$ & $89.25 \pm 0.55^{\mathrm{a}}$ \\
\hline 4. V. faba (Djunis) & $4.03 \pm 0.10^{\mathrm{b}}$ & $1.35 \pm 0.45^{\mathrm{b}}$ & $5.99 \pm 0.02^{\mathrm{a}}$ & $4.23 \pm 0.01^{\mathrm{c}}$ & $76.20 \pm 1.65^{\mathrm{b}}$ \\
\hline 5. V. faba (Selenča) & $2.42 \pm 0.05^{\mathrm{c}}$ & $0.52 \pm 0.12^{\mathrm{c}}$ & $1.74 \pm 0.02^{\mathrm{c}}$ & $5.58 \pm 0.04^{\mathrm{c}}$ & $37.12 \pm 2.08^{\mathrm{d}}$ \\
\hline average & $3.8^{\mathrm{A}}$ & $1.4^{\mathrm{A}}$ & $4.1^{\mathrm{A}}$ & $27.8^{\mathrm{B}}$ & $67.7^{\mathrm{A}}$ \\
\hline 6. V. narbonensis (Bulgaria) & $1.60 \pm 0.13^{\mathrm{c}}$ & $0.26 \pm 0.15^{\mathrm{c}}$ & $3.02 \pm 0.02^{\mathrm{c}}$ & $78.63 \pm 0.32^{\mathrm{a}}$ & $21.16 \pm 0.50^{\mathrm{d}}$ \\
\hline 7. V. serratifolia (Hopovo) & $3.99 \pm 0.10^{\mathrm{a}}$ & $0.58 \pm 0.24^{\mathrm{b}}$ & $2.44 \pm 0.02^{\mathrm{d}}$ & $81.73 \pm 0.15^{\mathrm{a}}$ & $67.56 \pm 2.37^{b}$ \\
\hline 8. V. sativa (cultivated) & $2.80 \pm 0.08^{\mathrm{b}}$ & $0.78 \pm 0.09^{\mathrm{b}}$ & $2.33 \pm 0.04^{\mathrm{d}}$ & $84.42 \pm 0.29^{\mathrm{a}}$ & $81.91 \pm 7.80^{\mathrm{a}}$ \\
\hline 9. V. ervilia (cultivated) & $1.95 \pm 0.12^{\mathrm{bc}}$ & $0.30 \pm 0.06^{\mathrm{c}}$ & $3.89 \pm 0.02^{\mathrm{a}}$ & $14.60 \pm 0.15^{\mathrm{c}}$ & $41.22 \pm 1.06^{\mathrm{c}}$ \\
\hline 10. V. pannonica (cultivated) & $4.15 \pm 0.42^{\mathrm{a}}$ & $1.96 \pm 0.43^{\mathrm{a}}$ & $3.22 \pm 0.02^{\mathrm{b}}$ & $51.95 \pm 0.03^{\mathrm{b}}$ & $89.62 \pm 0.69^{\mathrm{a}}$ \\
\hline average & $2.9^{\mathrm{B}}$ & $0.8^{\mathrm{B}}$ & $3.0^{\mathrm{B}}$ & $62.3^{\mathrm{A}}$ & $60.3^{\mathrm{A}}$ \\
\hline 11. G. max cv. Balkan & $3.18 \pm 0.01^{\mathrm{b}}$ & $1.28 \pm 0.04^{\mathrm{b}}$ & $0.51 \pm 0.06^{\mathrm{ab}}$ & $2.08 \pm 0.01^{\mathrm{a}}$ & $31.47 \pm 0.29^{b}$ \\
\hline 12. G. $\max$ cv. Alisa & $2.83 \pm 0.06^{\mathrm{c}}$ & $1.27 \pm 0.01^{\mathrm{b}}$ & $0.64 \pm 0.01^{\mathrm{a}}$ & $1.62 \pm 0.01^{\mathrm{b}}$ & $29.63 \pm 0.09^{\mathrm{c}}$ \\
\hline 13. G. max cv. Tara & $2.70 \pm 0.06^{\mathrm{c}}$ & $1.33 \pm 0.24^{\mathrm{b}}$ & $0.52 \pm 0.06^{\mathrm{ab}}$ & $1.66 \pm 0.06^{\mathrm{b}}$ & $27.47 \pm 0.19^{\mathrm{c}}$ \\
\hline 14. G. $\max \mathrm{cv}$. Venera & $3.51 \pm 0.17^{\mathrm{b}}$ & $1.36 \pm 0.03^{b}$ & $0.56 \pm 0.01^{\mathrm{a}}$ & $1.27 \pm 0.02^{\mathrm{c}}$ & $34.27 \pm 0.15^{\mathrm{b}}$ \\
\hline 15. G. max cv. Morava & $4.25 \pm 0.01^{\mathrm{a}}$ & $1.50 \pm 0.12^{\mathrm{a}}$ & $0.44 \pm 0.01^{\mathrm{b}}$ & $1.08 \pm 0.01^{\mathrm{d}}$ & $43.57 \pm 0.28^{\mathrm{a}}$ \\
\hline Average & $3.3^{\mathrm{A}}$ & $1.3^{\mathrm{A}}$ & $0.5^{\mathrm{C}}$ & $1.5^{\mathrm{C}}$ & $33.3^{\mathrm{B}}$ \\
\hline
\end{tabular}

TP: total polyphenols; TT: total tannins; FLA: flavonoids; PA: proanthocyanidins; DPPH: free radical scavenging activity

The \pm SE values marked with the same letter do not differ significantly at $(\mathrm{P}<0.05)$, difference among tested groups (uppercase) and within the group (lowercase)

Soybean cultivars were poor in FLA, having 6- to 8-fold lower amount of these substances in their seeds compared to faba beans and vetches. FLA can directly scavenge molecules of active oxygen, including $\mathrm{H}_{2} \mathrm{O}_{2},{ }^{1} \mathrm{O}_{2}$, and $\mathrm{O}_{2}-, \mathrm{OH}$, etc. They are also effective scavengers of peroxynitrite, a highly reactive oxidant formed when superoxide reacts with NO (Gould et al., 2002).

As expected, soybean seeds were also poor in PAs, another product of the FLA pathway, which exist as oligomers of leucoanthocyanidins. In our study, the average content was only $1.5 \mathrm{mg} \mathrm{g}^{-1}$ compared to faba beans $-27.8 \mathrm{mg} \mathrm{g}^{-1}$, and vetches $-62.3 \mathrm{mg} \mathrm{g}^{-1}$. The composition and content of free monomeric phenolic compounds of faba bean, vetches, and soybean seed preparations are presented in Table 2. 


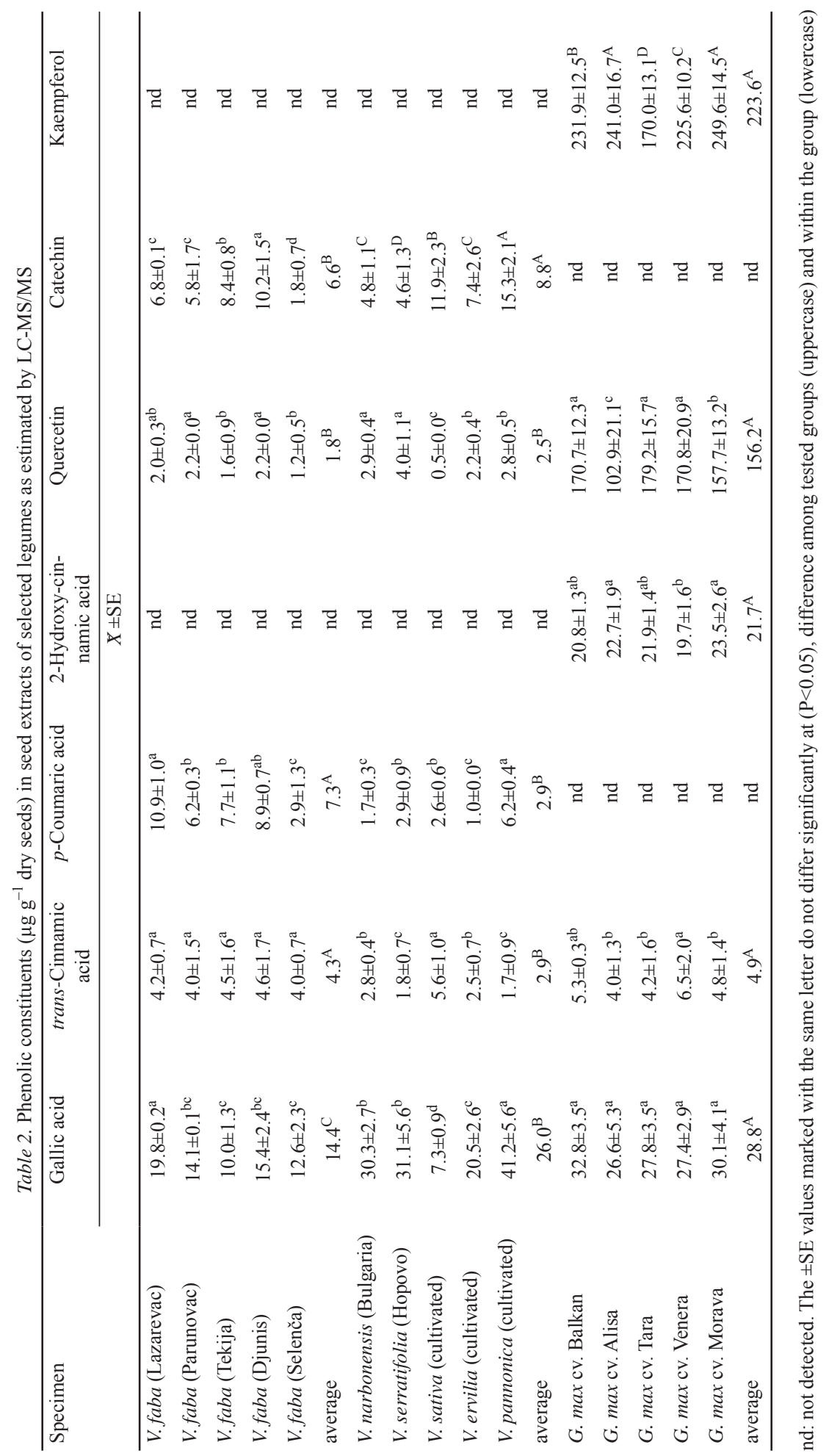




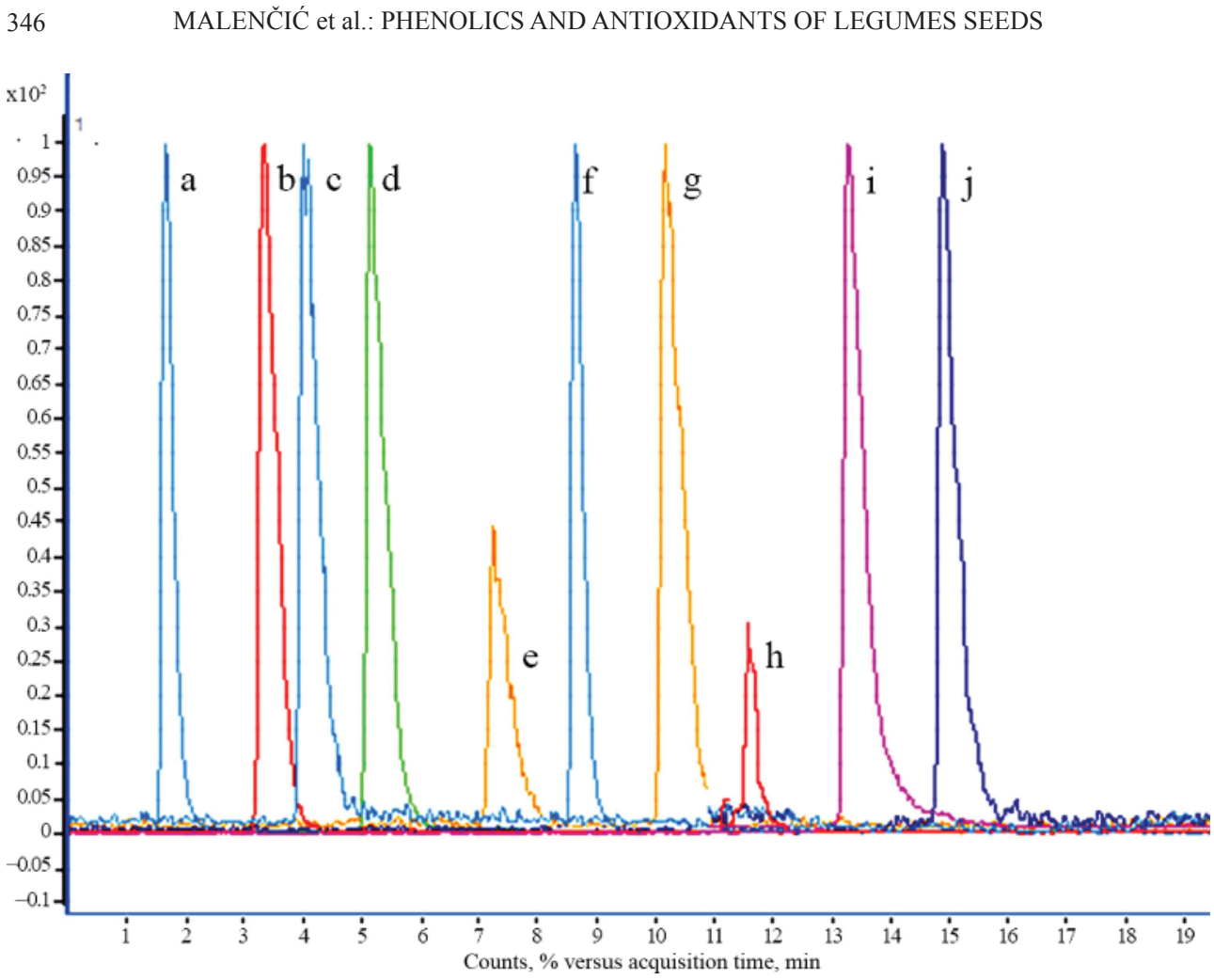

Fig. 1. LC-MS/MS chromatogram of the mixture of phenolic standards $(\mathrm{C}=1 \mu \mathrm{g} \mathrm{ml})$ a: gallic acid; b: (+)-catehin hydrate; c: chlorogenic acid; d: caffeic acid; e: 2-hydroxycinnamic acid; f: $p$-coumaric acid; g: ferulic acid; h: quercetin; i: trans-cinnamic acid; j: kaempferol

LC-MS/MS chromatogram of the mixture of phenolic standards is shown in Figure 1. The extracts of landraces and cultivars contained gallic and trans-cinnamic acids as their major phenolic compounds. Cinnamic acid derivatives, such as $p$-coumaric and ferulic acids, are known to be important components of cell walls of cereals (KAMISAKA et al., 1990). The 2-hydroxycinnamic acid was found only in soybean cultivars, the same as flavonoid kaempferol. Another flavonoid, quercetin, was found to be ubiquitous in all legumes investigated, where soybean samples were especially rich in this substance. Catechin was detected in faba bean and vetches, but not in the soybean samples. The flavonoid aglycones (7,3',4'-trihydroxyflavone, 7,4'-dihydroxyflavone, quercetin, and kaempferol) and flavonoid glycosides (quercetin 7-glucoside and kaempferol 7-glucoside) were identified from seed exudates of $V$. faba (Ho et al., 2002), which is in agreement with our findings for quercetin, but not for kaempferol. Due to a large amount of FLA and PA found in the seeds of faba bean and vetches, their extracts were more effective at scavenging of DPPH-radicals $(67.7 \%$ neutralized DPPH-radicals in faba beans and $60.3 \%$ in vetches, in average) compared to soybean seed extracts (33.3\%). According to the results of multiple regression analyses, the antioxidant activity of all investigated genotypes positively correlated with the TP content (Fig. 2). Additionally, the antioxidant capacity of faba beans positively correlated with FLA content (Fig. 3), while seed extracts of vetches showed a positive correlation between DPPHfree radical scavenging activity and the PA content (Fig. 4). 


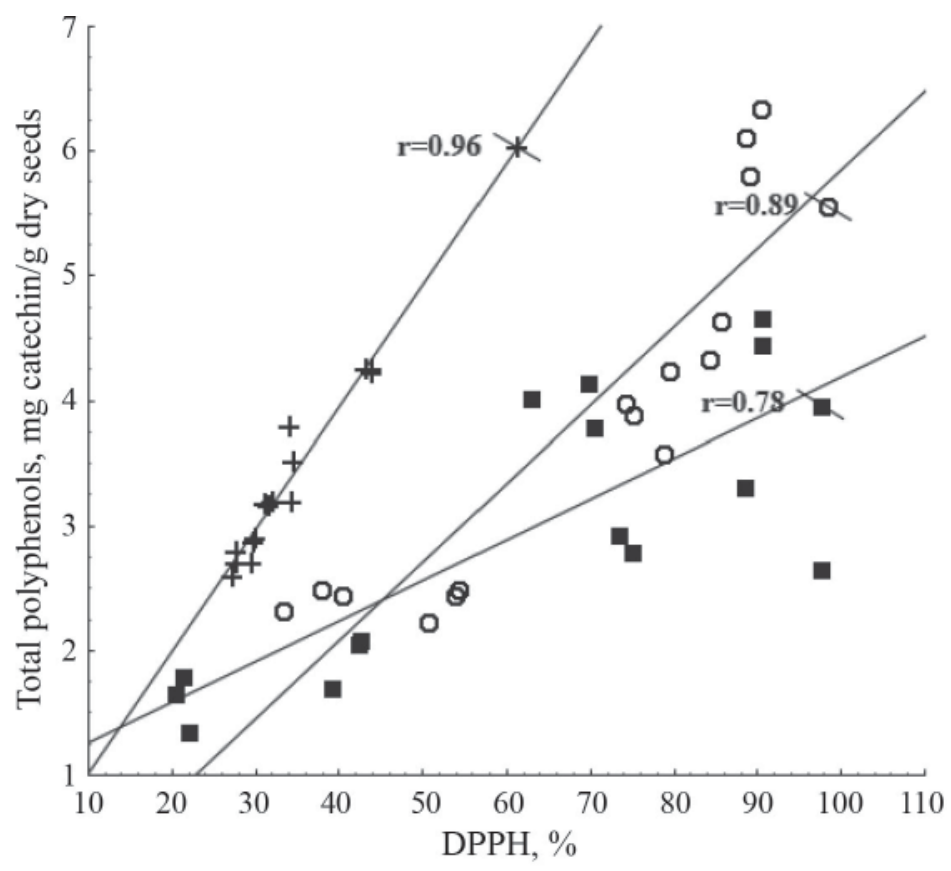

Fig. 2. Correlation between DPPH and TP in investigated legumes $Q$ : Faba bean; $\mathbf{Z}$ : vetches; +: soybean

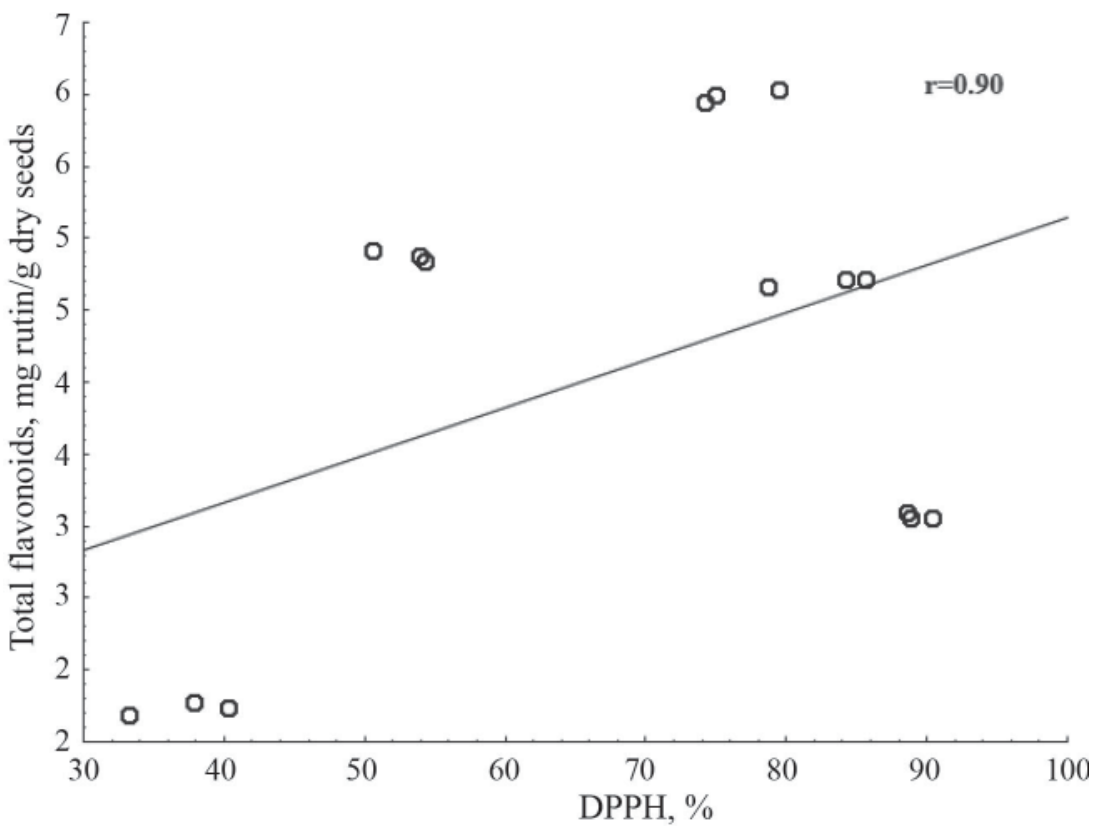

Fig. 3. Correlation between DPPH and FLA in investigated legumes 


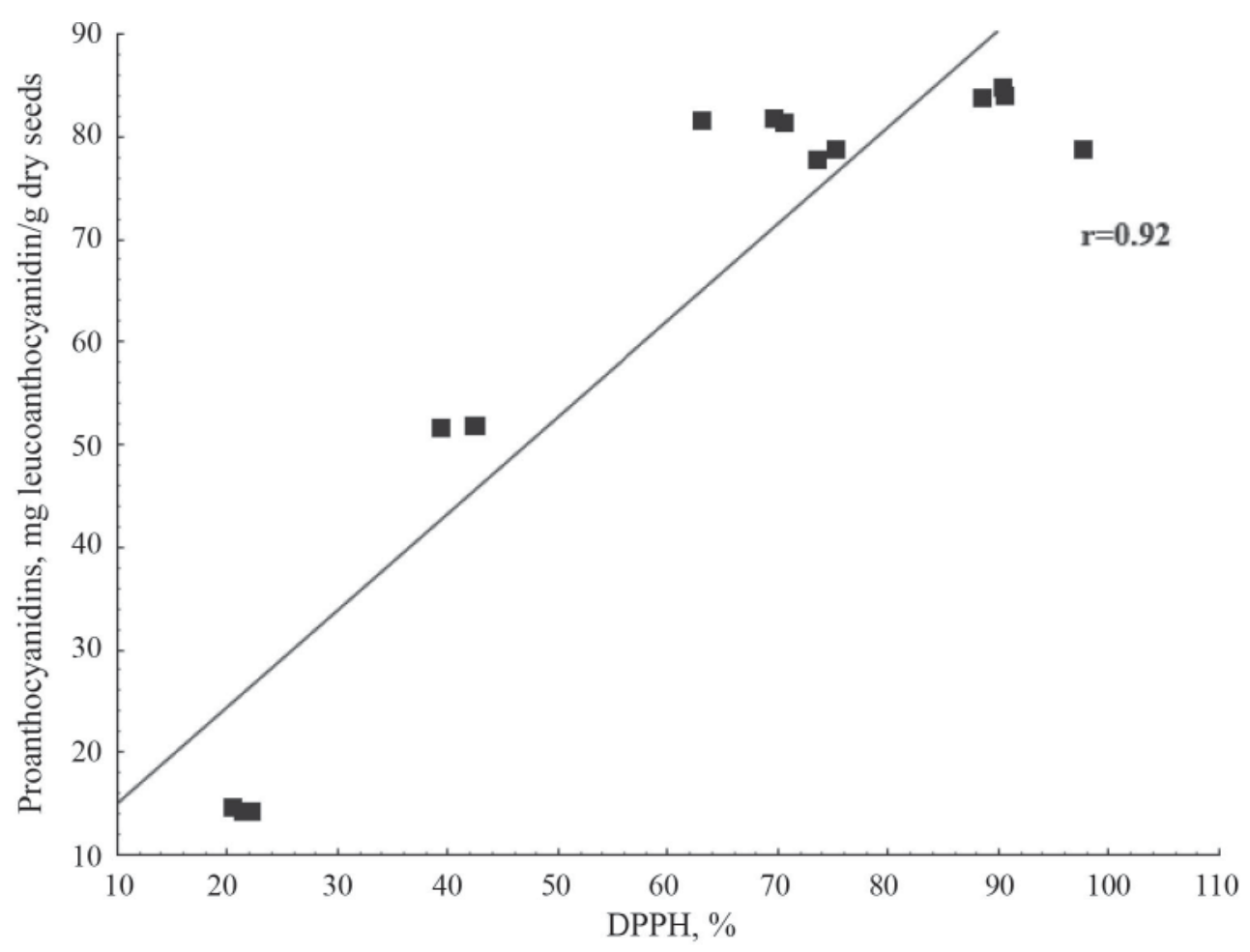

Fig. 4. Correlation between DPPH and PA in investigated legumes

\section{Conclusions}

Synergistic effect of phenolic classes seems to be unavoidable when assessing antioxidant capacity of plant extracts. Analyses showed that out of each group some perspective and interesting landraces/cultivars may be selected. From the group of faba beans almost all specimens show favourable traits - high TP, FLA, and PA contents, low TT content, and high DPPH-radical scavenging ability. In the vetches, a great diversity in investigated parameters has been established, but the contents of FLA and PA were significantly higher compared to seeds of commercially grown soybean cultivars. The results suggest that phenolics should be considered as an important feature of Vicia species, as some of its nutritive and pharmacological effects could be attributed to their presence.

This research was a part of the project of the South East Europe-Europe Research Area.NET Plus Joint Call "Sustainable preservation of indigenous South East European legumes and their traditional food and feed products" (SEEERA PLUS-168). Authors are grateful to the Ministry of Education, Science and Technological development, Republic of Serbia, Grant No. TR-31022. 


\section{References}

Addisu, S. (2016): Effect of dietary tannin source feeds on ruminal fermentation and production of cattle; a review. Online J. Anim. Feed Res., 6, 45-56.

Amidžić-Klarić, D., Klaric, I. \& Mornar, A. (2011): Polyphenol content and antioxidant activity of commercial blackberry wines from Croatia: Application of multivariate analysisfor geographic origin differentiation. $J$. Food Nutr. Res., 50, 199-209.

Baginsky, C., Pena-Neira, A., Caceres, A., Hernandez, T., Estrella, I., Morales, H. \& Pertuze, R. (2013): Phenolic compound composition in immature seeds of fava bean (Vicia faba L.) varieties cultivated in Chile. J. Food Compos. Anal., 31, 1-6.

Emmons, C.L. \& Peterson, D.M. (2001): Antioxidant activity and phenolic content of oat as affected by cultivar and location. Crop Sci., 41, 1676-1681.

Generalić, I., Skorza, D., Šurjak, J., Možina, S., Ljubenkov, I., Katalinić, A., Šimat, V. \& Katalinić, V. (2012): Seasonal variations of phenolic compounds and biological properties in sage (Salvia officinalis L.). Chem. Biodivers., 9, 441-457.

Goyoaga, C., Burbano, C., Cuadrado, C., Romero, C., Gullamon, E., Varela, A., Pedrosa, M.M. \& Muzquiz, M. (2011): Content and distribution of protein, sugars and inositol phosphates during the germination and seedling growth of two cultivars of Vicia faba. J. Food Compos. Anal., 24, 391-397.

Gould, K.S., McKelvie, J. \& Markham, K.R. (2002): Do anthocyanins function as antioxidants in leaves? Imaging of $\mathrm{H}_{2} \mathrm{O}_{2}$ in red and green leaves after mechanical injury. Plant Cell Environ, 25, 1261-1269.

Hagermann, A., Harvey-Muller, I. \& Makkar, H.P.S. (2000): Quantification of tannins in tree foliage - A laboratory manual. FAO/IAEA Working Document. International Atomic Energy Agency, Vienna, pp. 4-7.

Ho, H.M., Chen, R.Y., Leung, L.K., Chan, F.L., Huang, Y. \& Chen, Z.Y. (2002): Difference in flavonoid and isoflavone profile between soybean and soy leaf. Biomed. Pharmacother., 56, 289-295.

Kamisaka, S., Takeda, S., Takahashi, K. \& Shibata, K. (1990): Diferulic and ferulic acid in the cell wall of Avena coleoptiles: Their relationships to mechanical properties of the cell wall. Physiol. Plantarum, 78, 1-7.

MaKkar, H.P.S. (2003): Quantification of tannins in tree and shrub foliage: A laboratory manual. Kluwer Academic Publishers, 102 pages.

Malenčić, Đ., Popović, M. \& Miladinović, J. (2007): Phenolic content and antioxidant properties of soybean (Glycine max (L.) Merr.) seeds. Molecules, 12, 576-581.

Markham, K.R. (1989): Flavones, flavonols and their glycosydes. -in: Dey, P.M. \& Harborne, J.B. (Eds) Methods in plant biochemistry, Vol. 1. Plant phenolics. Academic Press, London, pp. 197-235.

Mihailović, V., Mikić, A., Vasić, M., Ćupina, B., Đurić, B., Duc, G., Stoddard, L.F. \& Hauptvogel, P. (2010): Neglected legume crops of Serbia - Faba bean (Vicia faba). Ratarstvo i povrtarstvo - Field Veg. Crops Res., 47, 27-32.

Mikić, A., Mihailović, V., Hauptvogel, P., Ćupina, B., Petrović, M., Krstić, Đ., Jovičić, D., Milošević, B. \& Hauptvogel, R. (2009): Wild population of vetches (Vicia) as forage and green manure crops for temperate regions. Irish J. Agr. Food Res., 48, 265

Mikić, A., Mihailović, V., Ćupina, B., ĐorĐević, V., Milić, D., Duc, G., Stoddard, L.F., Lejune-Henaut, I., Marget, P. \& HanocQ, E. (2011): Achievements in breeding winter-sown annual legumes for temperate regions with emphasis on the continental Balkans. Euphytica, 180, 57-67.

Puspitasari, W. (2017): Association analyses to genetically study reproduction and seed quality features of faba bean (Vicia faba L.). Ph.D. Dissertation, Faculty of Agricultural Sciences, Georg-August-University Göttingen, Germany. 86 pages.

Washida, K., Abe, N., SugiYAmA, Y. \& Hirota, A. (2007): Novel DPPH radical scavengers, demethylbisorbibutenolide and trichopyrone, from a fungus. Biosci. Biotech. Bioch., 71, 1052-1057. 